\title{
Mediating Effects of Career Stages on Job-Related Characteristics - Job Satisfaction Relationship
}

\author{
Vinko Lepojevic, Biljana Dordjevic, Maja Ivanovic-Djukic
}

\author{
University of Nis \\ Trgkralja Aleksandra Ujedinitelja 11, 18000 Nis, Republic of Serbia \\ E-mail.vinko.lepojevic@eknfak.ni.ac.rs,biljana.dordjevic@eknfak.ni.ac.rs,maja.ivanovic@eknfak.ni.ac.rs,
}

cross $^{\text {ref }}$ http://dx.doi.org/10.5755/j01.ee.29.2.18637

\begin{abstract}
Job satisfaction has occupied the attention of many authors for decades because this phenomenon has a great influence on many important outcomes in the workplace. Job satisfaction is, however, very complex phenomenon which is influenced by numerous contextual factors as well as job-content factors. Furthermore, there are also numerous factors which have a mediating effect on the relationship between job-related characteristics and job satisfaction. The aim of this paper is to analyze such effects. The main research question of this paper is whether job satisfaction at different career stages is influenced by different job-related characteristics. In order to answer this question, empirical research was conducted using a sample of 813 employees in the companies all over Serbia. The results of the study showed that in most cases jobrelated characteristics have a diverse influence on job satisfaction at different career stages. The results indicated that job-related characteristics, such as a relationship with co-workers and supervisors, operating procedures as well as communication have a greater influence on job satisfaction at the establishment career stage in comparison to other career stages. Promotion represents a job-related characteristic that has a greater influence on job satisfaction at the advancement stage in comparison to other stages. At the maintenance career stage, fringe benefits are the most influential, while at the decline stage those are contingent rewards. Finally, pay and the nature of work are job-related characteristics which have a similar effect on job satisfaction at all career stages.
\end{abstract}

Keywords: Job Satisfaction; Career Stages; Employees; Human Resource Management Practices; Job-Related Characteristics.

\section{Introduction}

Job satisfaction is one of the most researched topics in management literature taking into consideration the fact that it has been found out that this concept has many practical implications in the workplace. Some authors claim that this phenomenon is one of the three factors that successful companies share (the other two are strong performances and engagement with the business) (Bin, 2016). In addition to this, many studies have indicated that job satisfaction influences turnover intentions (Saeed, Waseem, Sikander, \& Rizwan, 2014; Larkin, 2015; Azeez, Jayeoba, \& Adeoye, 2016), organizational citizenship behavior (Foote \& Li-Ping Tang, 2008; Vatsa, 2013; Swaminathan \& Jawaha, 2013), organizational commitment (Azeem, 2010; Azeez et al., 2016), job performances ( $\mathrm{Gu} \& \mathrm{Chi}, 2009$; Chamundeswari, 2013; Bin, 2016), etc. But, job satisfaction is an extremely complex phenomenon. Firstly, there are numerous dimensions that can induce a sense of satisfaction. Secondly, there is a number of different individual factors (age, education, stage in career development, gender etc.) that may result in the fact that certain dimensions of job could be more important for some groups of employees than the other ones. The influence of these (individual) factors on job satisfaction has been the focus of many studies so far (Wharton, Rotolo, \& Bird, 2000; Sousa-Pouza, \& SousaPouza, 2000; Judge, \& Mount, 2002; Ilies \& Judge, 2003; Schneider, Hanges, Smith, \& Salvaggio, 2003). In this paper, however, we will examine the influence of career stages on job-related characteristics - job satisfaction relationship, since the influence of this mediating variable has been insufficiently investigated. We base this notion on the fact that this kind of research has mostly been done on the territory of developed countries so far (Franek \& Vecera, 2008). Developing countries, however, have many specificities compared with the developed countries, such as a high unemployment rate, low standard of living, etc., and these factors may give a new insight into the causality of job satisfaction. Moreover, this kind of research is usually conducted to analyse samples of members of specific professions.

On the basis of the above-mentioned, the main research problem of this paper is to identify job-related characteristics that have the greatest influence on job satisfaction at different career stages in organizations in Serbia regardless of their profession.

The paper has two aims. Firstly, to find out which jobrelated characteristics significantly influence job satisfaction of employees in Serbia at certain career stages and, secondly, to propose a set of human resource management (HRM) practices that will create more satisfied and, hopefully, more productive employees.

The paper is organized as follows. Initially, it will give an overview of the literature dealing with the concept of job satisfaction and present the development of the hypothesis. The second part will explain the methodology, put forward the results and provide a discussion section. The final part of the paper will submit recommendations for HRM, concluding remarks and the limitations to the study. 


\section{Literature Review}

For the majority of people, job is an essential part of their identity. Therefore, it is not surprising that, when introducing themselves, some people indicate their profession along with their name and surname (Judge \& Klinger, 2008). This manner is, however, typical of people who are satisfied with their job.

Job satisfaction, as a phenomenon, is usually seen as "a pleasurable or positive emotional state resulting from the appraisal of one's job or job experiences" (Locke, 1976 , p. 1304). Job satisfaction can also be defined as a result of a cognitive, affective and evaluative reaction of an individual to various job dimensions (Judge, Thoresen, Bono \& Patton, 2001). Crucial for understanding the nature of job satisfaction is the opinion that job satisfaction represents the level of divergence between what a worker expects to receive and what he/she actually experiences in the workplace (McShane, 2004). In that line, Fako, Moeng, and Forcheh (2009) state that, if one expects little from the job and gets little, he/she will be satisfied as much as the one who expects a lot and gets a lot. On the other hand, if one expects a lot from the job and gets little, he/she will be dissatisfied with it (Fako, Moeng \& Forcheh, 2009).

According to Spector (1997), job satisfaction could be seen as a global feeling about the job or as a constellation of attitudes about various aspects of the job, such as: pay, promotion, fringe benefits, contingent reward, supervision, co-workers, operating procedures, the nature of work and communication (Spector, 1997).

An important topic regarding job satisfaction is its causality. Concerning this issue, Judge and Klinger (2008) state that all studies that have investigated the causality of job satisfaction so far, actually, provide three models of job satisfaction: the dispositional model, interactional model and situational model.

The dispositional model of job satisfaction holds that certain relatively stable personality characteristics influence job satisfaction (Judge, Heller \& Mount, 2002). The personality characteristics that are usually analyzed in the context of job satisfaction causality are commonly those that are defined in the Big Five model (Goldberg, 1990). Some studies in this field have shown that the traits of neuroticism, extraversion, and conscientiousness display moderate correlations with job satisfaction. The other two traits agreeableness and openness to new experience - display relatively weak correlations with job satisfaction (Judge et al., 2002).

The interactional model of job satisfaction states that the person-environment fit influences the level of job satisfaction. In other words, the degree of congruence between job characteristics and abilities and needs of a job holder determines the level of job satisfaction (Thomas, Buboltz \& Winkelspecht, 2004).

The situational model of job satisfaction is based on the premise that job satisfaction stems from job characteristics such as skill variety, task identity, task significance, autonomy and feedback (Hackman \& Oldham, 1980) or from many other aspects of the work environment, such as the level of perceived job insecurity, pay, operational procedures, relationship with colleagues, relationship with superiors etc., (Spector, 1997; De Witte 1999; Oshagbemi,
2003; Spector, 2008; Giri \& Kumar, 2010; Djorjdevic, 2012; Hauff, Richter \& Tressin, 2015).

Despite the fact that the causality of job satisfaction is very often explored, this is still a fruitful area for research as there are some factors whose influence on job satisfaction has not been investigated sufficiently. As we have already said, career stages are among them, although there are some studies which have already analyzed the influence of these factors on job satisfaction. As far as the prior research in this field is concerned, Herbert and Burke (1997), for example, found out that context factors were more strongly correlated with job satisfaction than content factors at all career stages. Luttman, Mittermaier and Rebele (2003) discovered that a career stage was significantly related to tax accountants' performance and job-related tension, but unrelated to job satisfaction, organizational commitment, work alienation, and role stress. Further Menguc \& Bhuian (2004) observed that different job characteristics, except job variety, had a varying degree of impact on job satisfaction at different career stages. Finally, Schmit Jongbloed, SchönrockAdema, Borleffs, Steward, and Cohen-Schotanus (2017) noticed that physicians differed in pay satisfaction at different career stages.

However, the mediating influence of career stages on job-related characteristics - job satisfaction relationship from the perspective of Spector's job satisfaction model are quite rare. On the other hand, his model provides a very useful platform for a deeper understanding the causality of job satisfaction at different career stages taking into consideration that it contains broad set of job-related characteristics. This fact lies at the core of our research and the use of this particular model.

\section{The Hypotheses Development}

A career can be defined as "the pattern of work-related experiences that span the course of a person's life" (Greenhaus, Callanan \& Godshalk, 1999, p. 9). During this period, people go through several stages and face different expectations and needs regarding the job. "As the individual moves from the early career stages toward the later stages, their job focus changes from learning to seeking a higher salary to maintaining the earned position and, finally, to dissociating from the work" (Menguc \& Buhian, 2004, p. 216). However, while still at a certain career stage, individuals compare what they wanted from the job with what they gained. Greenhaus, Callanan and Goldshalk (1999) also state that "at each stage of development, the ratio of positive and negative experience determines the nature of the outcome" (Greenhaus et al., 1999, p. 109). One of the most important outcomes, undoubtedly, is job satisfaction.

Based on the above text, it is reasonable to expect that at different career stages different job-related characteristics influence employees' job satisfaction. Therefore, the first hypothesis we are going to test in our research is:

H1: Different job-related characteristics have a different influence on job satisfaction at various career stages.

Regarding career stages, several career development models have been developed (Table 1). 
Models of Career Development

\begin{tabular}{|c|c|c|}
\hline Author/s & Stage & Age \\
\hline Hall \& Nougaim, 1968 & $\begin{array}{l}\text { Pre-Work } \\
\text { Establishment } \\
\text { Advancement } \\
\text { Maintenance } \\
\text { Decline }\end{array}$ & $\begin{array}{c}0-25 \\
25-30 \\
30-45 \\
45-65 \\
\text { Over } 65 \\
\end{array}$ \\
\hline Levinson et al. (1978) & $\begin{array}{l}\text { Childhood } \\
\text { Early adulthood } \\
\text { Middle adulthood } \\
\text { Late adulthood }\end{array}$ & $\begin{array}{c}0-20 \\
20-40 \\
40-60 \\
\text { Over } 60 \\
\end{array}$ \\
\hline Greenhaus et al., 1999 & $\begin{array}{l}\text { Occupational choice/preparation for work } \\
\text { Organizational entry } \\
\text { Early career } \\
\text { Middle career } \\
\text { Late career }\end{array}$ & $\begin{array}{c}0-25 \\
18-25 \\
25-40 \\
40-55 \\
\text { 55- Retirement }\end{array}$ \\
\hline
\end{tabular}

Source: Authors

As for employees' different job expectations and needs at different career stages, the authors mostly agree that the primary concern of employees at the establishment stage is to settle on the career path and in the organization. Most newly-employed people enter an organization with an expectation that their job will be interesting, that they will use their talents and skills, that they will do something important, etc. (Greenhaus et al., 1999). Also, the newlyemployed expect to become accepted as equal and regular members of the organization. To become such a member, the first precondition is to learn organizational norms and values and to build an effective relationship with co-workers and supervisors. Having in mind all these needs and expectations of the newly employed, our second hypothesis is:

H2: The nature of work, operating procedures, relationship with co-workers and supervisors as well as communication have a greater influence on job satisfaction at the establishment stage compared with others stages.

At the advancement career stage, employees are usually concerned with promotion. Cron, Dubinsky, and Michaels (1988) maintain that at this career stage (although they call it the establishment stage) employees are mostly focused on promotion and the achievement of success. Greenhaus et al. (1999) similarly state that employees at the advancement stage (though they call it a period of achievement) are engrossed in various matters such as acquiring additional levels of responsibility and authority at work, demonstrating continual and increasing competence in individual assignments etc. On the basis of the aforementioned statements, we propose the following hypothesis:
H3: Promotion and pay have a greater influence on job satisfaction at the advancement stage in comparison to other career stages.

At the maintenance stage, employees tend to be more concerned with maintaining their present job status, position and performance level and less interested in working harder to achieve additional rewards (Flaherty \& Pappas, 2002). Since the number of opportunities for employee promotion frequently decreases at this stage (and, therefore, earnings level off), the major concern at this stage is whether an employee's compensation package is well-structured (in terms of monetary and non-monetary rewards). "For most people, this stage is a time of holding their own and maintaining what they have already achieved" (Cron \& Slocum, 1986, p. 120). Based on the above, we propose the following hypothesis:

H4: Fringe benefits have a greater influence on job satisfaction at the maintenance stage in comparison to other career stages.

At the decline stage employees are usually less interested in working harder to achieve additional incentives (earnings and promotion) but would rather enjoy the status for years working in an organization. Appreciation and recognition are very important to them. Since Spector's model of contingent rewards includes appreciation and recognition, we propose the following hypothesis:

H5: Contingent rewards have a greater influence on job satisfaction at the decline stage compared with other career stages.

The following table summarizes the most important job-related characteristics that bring about job satisfaction at different career stages.

Table 2

The Most Important Job-Related Characteristics That Bring About Job Satisfaction According to the Literature*

\begin{tabular}{|l|l|l|}
\hline \multicolumn{1}{|c|}{ Career stage } & \multicolumn{1}{|c|}{ Job-related characteristics important for job satisfaction } & \multicolumn{1}{c|}{ Author (s) } \\
\hline Establishment & $\begin{array}{l}\text { Nature of work, pay, the quality of relationship with peers. } \\
\text { Nature of work, relationship with co-workers, relationship with supervisors. }\end{array}$ & $\begin{array}{l}\text { Gould \& Hawkins, 1978 } \\
\text { Greenhaus } \text { et al., 1999 }\end{array}$ \\
\hline Advancement & $\begin{array}{l}\text { Pay increases, promotion, achieving success, job security. } \\
\text { Promotion. }\end{array}$ & $\begin{array}{l}\text { Cron et } \text { al., 1988 } \\
\text { Greenhaus et al., 1999 }\end{array}$ \\
\hline Maintenance & Pay/Fringe benefits. & Gould \& Hawkins, 1978 \\
\hline Decline & Recognition, appreciation (contingent rewards). & Greenahus et al. 1999 \\
\hline
\end{tabular}

Note*: Some of the job-related characteristics are reformulated in accordance with Spectors' model of job satisfaction, while career stages are defined in accordance with the career model used in the empirical research.

Source: Authors. 


\section{Method}

The context of the research. Serbia is the country in the Southeast of Europe with a population of around 7.2 million. Since 2001, this country has commenced undergoing the process of a political and economic transition. During this period, Serbia has plunged into recession three times. While the recession of 2009 was mainly a result of a severe impact of the international economic crisis, the 2012 and 2014 recessions were primarily caused by natural disasters (World Bank Group, Report No. 100464-YF, 2015). However, there have been some signs of economic recovery recently. The GDP growth for 2017 was expected to be around $3 \%$ (Economy of Serbia, 2017). In line of this sign of recovery, the unemployment rate in this country is still very high, particularly the unemployment rate of the young (34.9\%) (Labor Force Survey, 2016). Average earnings are also very low and are around 380 Euros (RS Official Gazette, 29/2017).

The sampling method and data collection. In order to test previously mentioned hypothesis, the primary research was conducted. We investigated the attitudes of employees in Serbian organizations on how job-related characteristics influence their job satisfaction. The research was carried out in the period from June to September 2016. The whole procedure of sampling was realized in two phases. In the first phase, we used a convenience sampling method that included final-year students of economic studies who were on the internship all over Serbia at the time of the research. A similar sampling was conducted by Duobienem, Duoba, Kumpikaite-Valiuniene, and Zickute (2015) in their research. In this way, we obtained the data from organizations from all parts of Serbia. In the second phase, the students were asked to hand out written quesitonnaires to the employees of the organizations which they did their internship in. One part of the questionnaire included questions related to the general information about the respondents: gender, age, years of service, level of education, and position in the organizational structure. The second part of the questionnaire included questions related to job characteristics which influence their job satisfaction.

Sample characteristics. Initially, the study included 1,000 respondents employed in 28 organizations operating on the territory of the Republic of Serbia. Out of 1,000 distributed questionnaires, 813 were usable, while 187 questionnaires were rejected due to inaccurate or incomplete answers. Regarding the structure of the sample, females accounted for $42.8 \%$, while the share of men was $57.2 \%$. The sample structure by age and education is given in the Table 3 .

Research variables and instruments. In order to measure job satisfaction, we used Spector's Job Satisfaction Survey (JSS) (Spector, 1985). This questionnaire is designed to assess employees' attitudes towards nine aspects of job that could influence job satisfaction, such as: pay, promotion, fringe benefits, contingent rewards, supervision, co-workers, operating procedures, the nature of work and communication. Each aspect of the job is assessed by four items (Spector, 1985) using a five-point Likert scale, ranging from 1 - strongly disagree, to 5 - strongly agree. The score of 4 or more expresses satisfaction; the score of 3 is used to denote a neutral opinion, while the scores below 3 are taken to indicate dissatisfaction. Since the questionnaire contains reverse questions, during the analysis a reversal of the initial coding was applied, so that in all questions high scores indicate great degrees of satisfaction, and vice versa.

Regarding career stages, we used Hall's and Nougaim's model (1968). However, we slightly modified it in order to get the one which will suit the employment context of Serbia. In our career model, instead of the age range from 0 to 24, a pre-work career stage ranges from 0 to 18 years since many individuals enter the labor market and get their first job after graduating from the high school (around the age of 18). However, in our research we limited the focus on the next four career stages: establishment (in our model, from 18 to 30 ) represented by number 1, advancement (from 31 to 45 ) represented by number 2, maintenance (from 46 to 60) represented by number 3 and decline (over 60) represented by number 4 . In our career model the decline career stage starts after 60 (instead of after 65 as it is proposed by Hall's and Nougaim`s model) because in Serbia the majority of employees end their careers at the age of 65. If we had assumed that the decline career stage starts at 65 , as it is in Hall's and Nougiam`s model, there would have been a possibility that no employee in our research would enter the decline career stage.

The Sample Structure in \%

Table 3

\begin{tabular}{|c|c|c|c|c|}
\hline \multirow{2}{*}{ Age } & \multicolumn{3}{|c|}{ Education } & Total \\
\cline { 2 - 5 } & Primary & Secondary & Post-secondary & 24.7 \\
\hline 25 and under & 1.0 & 12.7 & 11.0 & 28.8 \\
\hline $26-30$ & 1.1 & 16.0 & 13.0 & 30.6 \\
\hline $31-45$ & 1.0 & 16.6 & 6.6 & 14.4 \\
\hline $46-60$ & 0.5 & 7.3 & 0.8 & 1.5 \\
\hline over 60 & 0.1 & 0.6 & 43.1 & 100.0 \\
\hline Total & 3.7 & 53.2 & & \\
\hline
\end{tabular}

Source: Authors

Analyses and procedures. Correlation methods were applied in order to examine the relationship between satisfaction with certain job-related characteristics and average job satisfaction. In order to examine the influence of job-related characteristics on job satisfaction regression methods were applied. MANOVA was applied to test if different job-related characteristics had a different influence on job satisfaction at different career stages. The data were analyzed using the SPSS 17.0 software. 


\section{Results}

At the beginning of our analysis we checked the measure of internal consistency. Cronbach's Alpha value of 0.906 indicates a very good compatibility of the questions in the questionnaire for a given sample. Furthermore, we found that there is a high degree of correlation between each item and the overall results. Consequently, we hold that it is advisable that all items in the existing scale should remain, and that this scale is comparable to other studies which are based on such a scale.

Afterwards, we calculated the mean value of satisfaction for every job-related characteristic, average job satisfaction, as well as their interrelationship. The results of descriptive statistics and the results of the correlation analysis are presented in the Table 4.

Descriptive Statistics and Correlation Analyses

\begin{tabular}{|c|c|c|c|c|c|c|c|c|c|c|c|}
\hline Type of satisfaction & Mean & SD & 1 & 2 & 3 & 4 & 5 & 6 & 7 & 8 & 9 \\
\hline 1. Pay & 3.897 & 1.033 & 1 & & & & & & & & \\
\hline 2. Promotion & 3.719 & 1.147 & $.706^{* *}$ & 1 & & & & & & & \\
\hline 3. Fringe benefits & 3.984 & 1.082 & $.644^{* *}$ & $.639^{* *}$ & 1 & & & & & & \\
\hline 4. Contingent rewards & 4.343 & 1.046 & $.541^{* * *}$ & $.516^{* *}$ & $.475^{* *}$ & 1 & & & & & \\
\hline 5. Supervision & 3.574 & .999 & $.592^{* *}$ & $.516^{* *}$ & $.536^{* *}$ & $.507^{* *}$ & 1 & & & & \\
\hline 6. Co-workers & 3.535 & .950 & $.767^{* *}$ & $.703^{* *}$ & $.630^{* *}$ & $.618^{* *}$ & $.602^{* *}$ & 1 & & & \\
\hline 7. Operating procedures & 2.853 & .748 & $.424^{* *}$ & $.404^{* *}$ & $.344^{* *}$ & $.307^{* *}$ & $.184^{* *}$ & $.396^{* *}$ & 1 & & \\
\hline 8. Nature of work & 3.505 & .6498 & $.471^{* * *}$ & $.500^{* *}$ & $.479^{* *}$ & $.338^{* *}$ & $.346^{* * *}$ & $.431^{* *}$ & $.381^{* *}$ & 1 & \\
\hline 9.Communication & 3.495 & 1.178 & $.647^{* *}$ & $.726^{* *}$ & $.587^{* *}$ & $.567^{* *}$ & $.464^{* *}$ & $.620^{* * *}$ & $.354^{* *}$ & $.503^{* *}$ & 1 \\
\hline Average job satisfaction & 3.656 & 0.981 & $.859^{* *}$ & $.853^{* *}$ & $.894^{* * *}$ & $.927^{* *}$ & $.708^{* * *}$ & $.855^{* *}$ & $.527^{* *}$ & $.622^{* *}$ & $.820^{* *}$ \\
\hline
\end{tabular}

**The correlation is significant at the 0.01 level (2-tailed).

Source: Authors

As it is shown in the Table 4, the average job satisfaction of employees in Serbia is moderate (3.656). The Table 4 also shows that there are significant variations in the influence of different job-related characteristics on job satisfaction. The following job-related characteristics have the greatest impact on job satisfaction of employees in Serbia: contingent rewards (4.343), fringe benefits (3.984) and pay (3.897), while operating procedures (2.853) have the slightest influence on job satisfaction. The correlation analysis leads to the same conclusion. It was noticed that the strongest correlation exists among contingent rewards $(0.927)$, fringe benefits $(0.894)$ and pay (0.859), on the one hand, and average job satisfaction, on the other hand. The weakest correlation can be observed between operating procedures (0.527) and average job satisfaction. The correlation between all job-related characteristics and average job satisfaction is also statistically significant (at the level of $1 \%$ ).

In order to examine the influence of each job-related characteristic on job satisfaction in different career stages the regression analysis was applied. We created four linear regression models for each career stage. The dependent variable in the model was the average job satisfaction while the independent variables were job-related characteristics. The results of these models, i.e. the appropriate regressions coefficients, are presented in the Table 5.

To check the validity of our hypothesis, a multivariate analysis of variance was applied. An analysis was carried out in several steps. Firstly, we checked whether the assumptions for applying MANOVA were fulfilled: an adequate sample size, absence of multivariate outliers, multivariate normality, linear relationship between each pair of dependent variables, homogeneity of variancecovariance matrices, multicollinearity. We concluded that conditions for testing had been fulfilled.

In order to test the hypotheses, a multivariate analysis of variance was done. The results are presented in the Table 5.

Table 5

Regression Analysis and Multivariate Analysis of Variance

\begin{tabular}{|c|c|c|c|c|c|c|c|c|}
\hline \multirow{2}{*}{$\begin{array}{c}\text { Job-related } \\
\text { characteristics }\end{array}$} & \multicolumn{4}{|c|}{ Regression models $^{\mathbf{a}}$} & \multicolumn{4}{|c|}{ MANOVA } \\
\hline & $\begin{array}{l}\text { Model 1 } \\
\text { (Stage 1) }\end{array}$ & $\begin{array}{l}\text { Model } 2 \\
\text { (Stage 2) }\end{array}$ & $\begin{array}{r}\text { Model 3 } \\
\text { (Stage 3) } \\
\end{array}$ & $\begin{array}{l}\text { Model } 4 \\
\text { (Stage 4) }\end{array}$ & $\mathbf{F}$ & p-value & $\begin{array}{c}\text { Partial Eta } \\
\text { Square }\end{array}$ & Bonferroni \\
\hline Pay & $\begin{array}{l}.280 \\
(.688)\end{array}$ & $\begin{array}{l}.294 \\
(.691)\end{array}$ & $\begin{array}{l}.250 \\
(.652)\end{array}$ & $\begin{array}{l}.239 \\
(.650)\end{array}$ & 3.163 & NS* & .012 & - \\
\hline Promotion & $\begin{array}{l}.180 \\
(.305)\end{array}$ & $\begin{array}{l}.313 \\
(.742)\end{array}$ & $\begin{array}{l}.191 \\
(.379)\end{array}$ & $\begin{array}{l}.084 \\
(.195)\end{array}$ & 11.685 & .000 & .042 & $1-3,1-4,2-3,2-4$ \\
\hline Fringe benefits & $\begin{array}{l}.153 \\
(.405)\end{array}$ & $\begin{array}{l}.047 \\
(.307)\end{array}$ & $\begin{array}{l}.278 \\
(.496)\end{array}$ & $\begin{array}{l}.157 \\
(.430)\end{array}$ & 15.519 & .000 & .054 & $1-4,2-4$ \\
\hline Contingent rewards & $\begin{array}{l}.083 \\
(.514)\end{array}$ & $\begin{array}{l}.204^{*} \\
(.606)\end{array}$ & $\begin{array}{l}.271 \\
(.657)\end{array}$ & $\begin{array}{l}.323 \\
(.753) \\
\end{array}$ & 36.729 & .000 & .120 & $\begin{array}{c}1-2,1-3,1-4,2-3 \\
3-4\end{array}$ \\
\hline Supervision & $\begin{array}{l}.234 \\
(.491) \\
\end{array}$ & $\begin{array}{l}.098 \\
(.196)\end{array}$ & $\begin{array}{l}.131 \\
(.311)\end{array}$ & $\begin{array}{l}.069 \\
(.139) \\
\end{array}$ & 10.234 & .000 & .037 & $1-2,1-3,2-4$ \\
\hline Co-workers & $\begin{array}{l}.186 \\
(.371) \\
\end{array}$ & $\begin{array}{l}.103 \\
(.233)\end{array}$ & $\begin{array}{l}.028^{*} \\
(.055)\end{array}$ & $\begin{array}{l}.097 \\
(.189)\end{array}$ & 13.062 & .000 & .046 & $1-2,1-3,1-4,2-4$ \\
\hline $\begin{array}{l}\text { Operating } \\
\text { procedures }\end{array}$ & $\begin{array}{l}.188 \\
(.237)\end{array}$ & $\begin{array}{l}.078 \\
(.145)\end{array}$ & $\begin{array}{l}.027^{*} \\
(.047)\end{array}$ & $\begin{array}{l}.045 \\
(.069)\end{array}$ & 4.072 & .007 & .015 & $1-2,1-3,1-4,2-, 3-4$ \\
\hline Nature of work & $\begin{array}{l}.242 \\
(.268)\end{array}$ & $\begin{array}{l}.234^{*} \\
(.257)\end{array}$ & $\begin{array}{l}.231 \\
(.247)\end{array}$ & $\begin{array}{l}.241 \\
(.267)\end{array}$ & 2.845 & NS* & .010 & - \\
\hline
\end{tabular}


Vinko Lepojevic, Biljana Dordjevic, Maja Ivanovic-Djukic. Mediating Effects of Career Stages on Job-Related...

\begin{tabular}{|c|c|c|c|c|c|c|c|c|}
\hline \multirow[b]{2}{*}{$\begin{array}{c}\text { Job-related } \\
\text { characteristics }\end{array}$} & \multicolumn{4}{|c|}{ Regression models $^{\mathrm{a}}$} & \multicolumn{4}{|c|}{ MANOVA } \\
\hline & $\begin{array}{l}\text { Model 1 } \\
\text { (Stage 1) }\end{array}$ & $\begin{array}{l}\text { Model } 2 \\
\text { (Stage 2) }\end{array}$ & $\begin{array}{l}\text { Model 3 } \\
\text { (Stage 3) }\end{array}$ & $\begin{array}{l}\text { Model } 4 \\
\text { (Stage } \\
\text { 4) }\end{array}$ & $\mathbf{F}$ & p-value & $\begin{array}{l}\text { Partial } \\
\text { Eta } \\
\text { Square }\end{array}$ & Bonferroni \\
\hline Communication & $\begin{array}{c}.241 \\
(.299)\end{array}$ & $\begin{array}{l}.089 \\
(.249)\end{array}$ & $\begin{array}{l}.071 \\
(.164)\end{array}$ & $\begin{array}{l}.073 \\
(.184)\end{array}$ & 15.449 & .000 & .054 & $1-3,2-3,3-4$ \\
\hline $\mathrm{R}^{2}$ & 0.960 & .841 & .887 & .908 & & & & \\
\hline Adjusted $\mathrm{R}^{2}$ & 0.952 & .834 & .881 & .905 & & & & \\
\hline
\end{tabular}

a Standardized Coefficients Beta are between brackets

* Non-significant

Source: Authors

As the Table 5 shows, that most regression coefficients are statistically significant at a significance level of $5 \%$, except two coefficients in the second model and two coefficients in the third model (marked *). Also, there is a very high degree of explanation of the variability in regression models in ranges from $84.1 \%$ in the second model to $96 \%$ in the first model $\left(\mathrm{R}^{2}\right)$.

The strength of the impact of particular job-related characteristics on average job satisfaction is expressed by standardized Beta coefficients whose values are given in the brackets, while the amounts without bracket are nonstandardized Beta coefficients.

Table 5 shows that pay is a job-related characteristic which has high influence on average job satisfaction $(0,650<\mathrm{B}<0,691)$, but this influence is similar at all career stages. We may conclude that pay significantly influences job satisfaction regardless of a career stage. The situation is similar when it comes to the nature of work. Influence of nature of work on average job satisfaction $(0,247<\mathrm{B}<0,268)$ is smaller compared to the influence which has pay, but this influence is similar at all career stages.

All the others job-related characteristics (promotion, contingent rewards, fringe benefits, operating procedures, communication, a relationship with supervisors and coworkers) have a significantly different influence on job satisfaction at different career stages (the information about statistically significant differences between job satisfaction at different career stages viewed from the point of job characteristics can be found in the Table 5, the column p-value and Bonferroni column). So, our first hypothesis (H1) that (all) different job-related characteristics have a different influence on job satisfaction at different career stages was not confirmed.

Regarding the second hypothesis $(\mathrm{H} 2)$, we assumed that job characteristics such as the nature of work, operating procedures, a relationship with co-workers and supervisors, as well as the communication in an organization have a greater influence on job satisfaction at the establishment stage in comparison to other career stages. The results in the Table 5 indicate that satisfaction with each of the above mentioned job-related characteristics at this stage is deeper compared to the satisfaction with the same job-related characteristics at other stages.

The Table 5 also shows that the influence of a relationship with co-workers (B-0,371) and supervisors (B$0,491)$, operating procedures $(\mathrm{B}-0,237)$ and communication (B-0,299) on job satisfaction at the establishment stage are greater than at others career stages. Nevertheless, this is not the case with the nature of work. As noted above, this job-related characteristic has approximately the same impact on the job satisfaction at all stages of career.
Bearing in mind the previously presented results, we may conclude that the hypothesis $\mathrm{H} 2$ was not confirmed.

Our third hypothesis (H3) was that promotion and pay have greater influence on job satisfaction at the advancement stage in comparison to other career stages. The results we obtained show that influence of promotion on job satisfaction at this stage is significantly bigger (B0,742) in comparison to other stages. However, the influence of pay on job satisfaction at the advancement stage is not significantly different compared to the other stages (as noted above, pay has approximately the same impact on job satisfaction at all career stages). We may conclude that the hypothesis $\mathrm{H} 3$ was not confirmed.

Our fourth hypothesis (H4) was that fringe benefits have a greater influence on job satisfaction at the maintenance stage compared with other career stages. The results we obtained show that satisfaction with fringe benefits at the maintenance stage is higher compared with the satisfaction with both the same job characteristics at other stages (B-0,496). Therefore, we may conclude that the hypothesis $\mathrm{H} 4$ was confirmed.

Our fifth hypothesis (H5) was that contingent rewards have a bigger influence on job satisfaction at the decline stage in comparison to other career stages. The obtained results show that satisfaction with contingent rewards at the decline stage is significantly higher compared to both the satisfaction with contingent rewards at other stages (B0,753). Therefore we may conclude that the hypothesis H5 was confirmed.

\section{Discussion}

Based on the literature on job satisfaction and career development, we assumed that different job-related characteristics have a different influence on job satisfaction at different career stages. Our assumptions were confirmed regarding the hypothesis $\mathrm{H} 4$ and $\mathrm{H} 5$.

Despite the fact that our career development model is to some extent different from some extant career development models, the results obtained in the research are somewhat similar to the findings of other authors. For example, the study conducted by Mount (1984) revealed that managers at the establishment stage were more satisfied with their immediate supervisor, pay, company practices and career development than managers at other career stages. Our findings are in line with the results of this study, particularly when it comes to the influence of a relationship with supervisors and operating procedures (called company practices in Mont`s model).

To a certain degree, our findings regarding the hypothesis $\mathrm{H} 2$ are similar to the results of the study 
conducted by Slocum and Cron (1985). In their study, job satisfaction at the establishment stage (or the trial stage, as they call it) is also mostly influenced by the relationship with co-workers and supervisors (as well as with work itself) (Slocum \& Cron, 1985). Furthermore, our findings that a relationship with supervisors has a stronger influence on job satisfaction at the establishment stage in comparison to other stages is similar to the findings provided by Menguc and Bhuian (2004). As a matter of fact, they found out that job feedback (which is a relationship with a supervisor in our model) is a stronger determinant of a guest worker salesperson's job satisfaction at the early career stage than at later career stages (Menguc \& Bhuian, 2004).

We came to the conclusion that promotion has a bigger influence on job satisfaction at the advancement career stage than at other stages. However, the results are different from the ones put forward in Mount's study which revealed that career development (in our model promotion) produces a higher level of managers' job satisfaction at the establishment stage in comparison to the advancement and maintenance stage (Mount, 1984). The explanation for this divergence might be found in employees' expectations at these career stages: what these particular employees expected and what they gain regarding this job-related characteristic.

As far as pay is concerned, the obtained results from the research show that it has no statistically significant different influence on job satisfaction at different career stages. The explanation for such results could be found at the fact that the unemployment rate in Serbia is very high and that the standard of living is very low; hence, the possibility of having pay and other rewards at all induces a high level of job satisfaction regardless of the career stage which employees are at.

The obtained research findings that fringe benefits are job-related characteristics which have a stronger influence on job satisfaction at the maintenance career stage in comparison to other stages are consistent with the opinion of Cron et al. (1988). Namely, they state that employees at the maintenance career stage tend to be more concerned with maintaining their present job status, position and performance level. In other words, employees at this career stage express less interest in working harder to achieve additional rewards.

Employees at the decline stage tend to psychologically separate themselves from their work (Cron et al., 1988). Contrary to this conclusion, our analysis showed that appreciation and recognition of good work (contingent reward) produce greater job satisfaction at this career stage compared with other stages. The explanation for this phenomenon involves the fact that the decline career stage in our research model starts at the age of 60 , when people still want to contribute to the development of their organizations. In other models, this stage usually begins after the age of 65 .

\section{Implication for Human Resource Management Practices}

On the basis of the assertion that HRM practices have a pivotal role in providing appropriate employees' behavior (Berber, Susnjar Stangl, Slavic, \& Baosic 2014) and the results obtained from the study, in this section we are going to propose some human resource management (HRM) practices which, we believe, could result in more satisfied and, probably, more productive employees.

According to the obtained results, a relationship with co-workers and supervisors is a job-related characteristic that has a substantial influence on job satisfaction at the establishment career stage. Having in mind that this jobrelated characteristic has a stronger impact on employees' job satisfaction at the establishment career stage in comparison to other stages, we recommend that HR managers in Serbia should pay assiduous attention to creating good interpersonal relationships not only among new employees and co-workers but also among new employees and supervisors. In order to create good relationships with them, useful measures also include an appropriate socializing of newcomers and promoting the climate of openness and fun at work (Obakpolo, 2015; Allen, 2006; Berman, West, Richter, \& Maurice, 2002). Besides these practices, we also suggest that the personal traits important for building a cohesive workforce and positive interpersonal relationships should be subject to careful scrutiny within the selection process (Obakpolo, 2015).

Communication also has a considerable influence on job satisfaction of employees at the establishment stage in organizations in Serbia. This is, however, an important jobrelated characteristic for every workplace since its objectives are twofold: to inform the workforce about their tasks and the policy issues of the organization and to construct a community (De Ridder, 2003). Having in mind that this job-related characteristic has a greater influence on job satisfaction at the establishment stage in comparison to other stages, HR management in Serbia should find the ways to improve this area. As the majority of young employees are familiar with using the information technology, they could make use of this advantage and open new communication channels with the management.

Moreover, operating procedures have a greater influence on job satisfaction at the establishment stage than at any other stage. Although the standard operation procedures are very important for the output consistency and efficiency (De Trevil, Antonakis, \& Edelson, 2005), it is necessary to raise the satisfaction with them. Therefore, we recommend that, whenever it is possible, management teams in Serbian or Oganizations should allow new employees to put forward their suggestions about the improvement of the work process. This is essential because they could bring new insights and fresh ideas about how to improve all these segments. Generally, employees highly appreciate the operating procedures which enable them to participate in their development (Adler, 1993, Hackman \& Wageman, 1995).

Furthermore, the results of the study show that promotion has a bigger impact on job satisfaction at the advancement career stage compared with other stages. Hence, in order to raise job satisfaction at this career stage 
Vinko Lepojevic, Biljana Dordjevic, Maja Ivanovic-Djukic. Mediating Effects of Career Stages on Job-Related...

in Serbian organizations, we propose that promotional procedures which encourage the promotion of best performers should be implemented.

The obtained results point to the fact that fringe benefits have a more considerable influence on job satisfaction of employees at the maintenance career stage than at other career stages. Since employees at the maintenance stage are very important for the organizations due to their experience, the management in Serbian organizations should put a special emphasis on this part of the compensation package for such employees. Specially devised specific and attractive fringe benefits could serve as a means of retaining highly valuable employees, or as a mode of strengthening other employees' commitment, motivation, productivity and job performance (Soon Yew, LaiKuan, Zaliha \& Kamaruzaman, 2008).

Finally, the results showed that appreciation and recognition, i.e. contingent rewards, have a greater influence on job satisfaction at the decline career stage in comparison to other career stages. Therefore, the management in organizations in Serbia should focus on non-monetary rewards of elderly workers in order to make them more satisfied with the job. Elderly workers have been typically viewed as lacking several competences, including productivity, efficiency, capability of working under pressure, receptivity to new ideas, etc. Yet, they can be dedicated, productive and enthusiastic employees "but must be treated with dignity and respect and must be recognized for their value to the firm" (Greenhaus et al., 1999, p. 236). In that sense, company anniversaries and other important events are a marvelous opportunity for expressing the recognition and appreciation of elderly workers' corporate achievements. Appreciation and recognition could also be expressed by giving them mentoring assignments. Since retirement, as a radical shift in the career, is the next phase of their life, psychological counseling for starting a potential prospective new career will also be a useful method of keeping their morals on a high level.

The research we conducted showed that pay strongly influences job satisfaction regardless of the career stage. Therefore, in order to induce high satisfaction with this job-related characteristic, some rules should be applied: each person should be paid fairly on their merit, and in accordance with their efforts, abilities and training; pay should boost effective and productive work; employees should understand the pay system and feel it is a reasonable system for the enterprise and themselves (Ivancevich, 2010).

The research also demonstrated that there is statistically significant difference between the influences of the nature on work on job satisfaction at different career stages and that the influence is relatively weak. In line with this, we recommend redesigning a job whenever it is possible so that employees could exercise a variety of skills, expressing creativity and innovativeness, etc. In turn, employers may expect not only the higher job satisfaction of employees, but also reduced turnover and many other positive outcomes (Parker, 2014).

\section{Theoretical Implications of the Paper}

This research will potentially contribute to the extant base of knowledge in this filed in several ways.

Firstly, we investigated the influence of career stages on the relationship among job-related characteristics and job satisfaction - an area which has not been sufficiently investigated on the territory of developing countries. Therefore, the obtained results may give an additional insight into the relationship among job-related characteristics and job satisfaction. One conclusion is particularly important for enriching the existing knowledge base in this field: if the standard of living is very low and the unemployment rate is very high, pay is the very influential factors of job satisfaction regardless of the career stage.

Secondly, we did not limit our research to a particular profession as studies in this field mostly did. Therefore, we believe that our conclusions might have universal elements.

Thirdly, since this kind of study has not been carried out in Serbia, this research can bridge a knowledge gap in the domestic literature on HR management and industrial psychology.

\section{Conclusion}

In this paper we investigated the influence of career stages on the job-related characteristics-job satisfaction relationship of employees in enterprises in Serbia. We examined whether at different career stages job satisfaction is influenced by different job-related characteristics specified in Spector`s model.

The research showed that career stages mediate the relationship between job-related characteristics and job satisfaction in all cases except for pay and the nature of work. In other words, all other job-related characteristics have a diverse significance for job satisfaction at different career stages.

The research showed that a relationship with coworkers and with supervisors, as well as operating procedures and communication are job-related characteristics that have a greater influence on job satisfaction at the establishment stage in comparison to all other stages. The results also showed that at the advancement career stage, satisfaction with promotion is higher than at other career stages. Further, at the maintenance career stage, the influence of fringe benefits on job satisfaction is bigger than at other career stages. Finally, at the decline career stage, satisfaction with contingent rewards is stronger compared with other career stages.

Based on the results we obtained from the research, we proposed a set of HRM practices in order to increase job satisfaction of employees at certain career stages. The proposed HRM practices for increasing the job satisfaction at the establishment career stage encompass an appropriate socializing of the newcomers, promoting the climate of openness and fun at work, using information technology for opening new channels of communication with the management, participating in the development of operational procedures, etc. The proposed HRM practices 
for the advancement career stage include the implementation of promotional procedures that will enable the best performers to be promoted. The proposed HRM practices for managing job satisfaction at the maintenance career stage consist of providing specific and attractive fringe benefits which will serve as a means of retaining highly valuable employees, or strengthening employees' commitment, motivation, productivity and job performance. When it comes to the decline career stage, we proposed psychological counseling, as well as giving mentoring assignments.

\section{Limitations to the Study}

The study we conducted has several limitations. Firstly, the limitation of the study refers to the measurement of career stages. In this study, career stages were measured by an indirect method (ages) but the ages in some cases are not a representative indicator of the career stage in which a particular employee is. For example, someone aged 40 may still be at the establishment career stage since they changed the organization.

Secondly, our model of career stages is based on the career development process which is, to some extent, typical of the local (Serbian) context in which the majority of employees end their career between the ages of 60 to 65 , while the scholars from this field put forward career development models in which employees usually end their careers after the age of 65 . Consequently, the results we obtained may not be comparable enough with the results of the studies that have already been conducted in this area.

\section{Guidelines for Future Research}

The subjects of our research were only those jobrelated characteristics inducing a sense of job satisfaction at certain career stages that had been suggested by scholars from this field. However, in order to get more reliable results and propose more effective HRM management practices for increasing the job satisfaction of employees, similar research should be conducted in two phases. In the first phase, the research should identify what employees at certain career stages really expect to gain from the job. In the second phase the level of job satisfaction of these dimensions should be addressed. By applying a ratio approach (what someone expected and what they gained), the management could implement more personalized, and, hence, more effective measures for increasing the satisfaction of employees.

\section{References}

Adler, P. S. (1993). Time-and-motion regained. Harvard Business Review, 71, 97-108.

Ahmad, N. M., \& Ashraf, N. (2015). Career Stage Effect on Organizational Commitment. International Journal of Science and Research, 4(3), 171-177.

Allen, D.G. (2006). Do organizational socialization tactics influence newcomer embeddedness and turnover? Journal of Management, 32(2), 237-256. https://doi.org/10.1177/0149206305280103

Azeem, S. M. (2010). Job satisfaction and organizational commitment among employees in the Sultanate of Oman. Psychology, 1(4), 295-300. https://doi.org/10.4236/psych.2010.14038

Azeez, R. O., Jayeoba, F., \& Adeoye, A. O. (2016). Job Satisfaction, Turnover Intention and Organizational Commitment. Journal of Management Research, 8 (2), 102-114.

Berber, N., Susnjar Stangl, G., Slavic, A., \& Baosic, M. (2014). Relationship between Corporate Social Responsibility and Human Resource Management - as New Management Concepts - in Central and Eastern Europe. Inzinerine Ekonomika-Engineering Economics, 25(3), 360-369. https://doi.org/10.5755/j01.ee.25.3.4222

Berman, E.M., West, J. P., Richter, J., \& Maurice, N. (2002). Workplace relations: Friendship patterns and consequences. Public Administration Review, 62, 217-230. https://doi.org/10.1111/0033-3352.00172

Bin, A. S. (2015). The relationship between job satisfaction, job performance and employee engagement: An explorative study. Issues in Business Management and Economics, 4(1), 1-8. Available at: http://journalissues.org/wp-content /uploads/2016/01/Abdulwahab.pdf.

Bin, A. S. (2016). The relationship between job satisfaction, job performance and employee engagement: An explorative study. Issues in Business Management and Economics, 4(1), 1-8.

Chamundeswari, S. (2013). Job satisfaction and performance of school teachers. International Journal of Academic Research in Business and Social Sciences, 3(5), 420-428.

Cron, W. L., Dubinsky, A. J., \& Michaels, R. E. (1988). The Influence of Career Stages on Components of Salesperson Motivation. Journal of Marketing, 52 (1), 78-92. https://doi.org/10.2307/1251687

Cron,W. L., \& Slocum, J. W. Jr. (1986). The Influence of career stages on salespeople's job attitudes, work perceptions and performance. Journal of Marketing Research, 23(2), 119-129. https://doi.org/10.2307/3151659

De Witte, H. (1999). Job insecurity and psychological well-being: Review of the literature and exploration of some unresolved issues. European Journal of Work and Organizational Psychology, 8 (2), 155-7. https://doi.org/10.1080/135943299398302

De Ridder, J. (2003). Organizational communication and supportive employees. Human Resource Management Journal, 4(4), 1-10. 
Vinko Lepojevic, Biljana Dordjevic, Maja Ivanovic-Djukic. Mediating Effects of Career Stages on Job-Related...

De Trevil, S., Antonakis, J., \& Edelson, N. (2005). Can Standard Operating Procedures be Motivating? Reconciling Process Variability Issues and Behavioral Outcomes. Total Quality Management, 16(2), $231-241$. https://doi.org/10.1080/14783360500054236

Djordjevic, B. (2012). Nesigurnost zaposlenja - priroda, posledice i strategije upravljanja [Employment insecurity - nature, consequences and management strategies]. Teme, 36 (1), 335-350.

Duobiene, J., Duoba, K., Kumpikaite-Valiuniene, V., \& Zickute, I. (2015). Networking and Virtuality in Entrepreneurial Organisations in the Age of Countries without Borders. Inzinerine Ekonomika-Engineering Economics, 26(5), 530540. https://doi.org/10.5755/j01.ee.26.5.13145

Economy of Serbia. (2017). Available at: http://www.pks.rs/PrivredaSrbije.aspx

Fako, T. T., Moeng, S. R. T., \& Forcheh, N. (2009). Gender differences in satisfaction with the type of work university employees do: evidence from the University of Botswana. Journal of Service Science and Management, 2, $404-417$. https://doi.org/10.4236/jssm.2009.24049

Flaherty, K. E., \& Pappas, J. M. (2002). The influence of career stages on job attitudes: Towards a contingency perspective. Personal Selling and Sales Management, 22 (3), 135-144.

Foote, D. A., \& Li-Ping Tang, T. (2008). Job satisfaction and organizational citizenship behavior (OCB); Doesteam commitment make a difference in self-directed teams? Management Decision, 46(6), 933-947. https://doi.org/10.1108/00251740810882680

Franek, M., \& Vecera, J. (2008). Personal characteristics and job satisfaction. Ekonomika A Management, 4, 63-76.

Giri, V. N., \& Kumar, B. P. (2010). Assessing the impact of organizational communication on job satisfaction and job performance. Psychological Studies, 55(2), 137-143. https://doi.org/10.1007/s12646-010-0013-6

Goldberg, L. R. (1990). An alternative "description of personality": The Big-Five factor structure. Journal of Personality and Social Psychology, 59, 1216-1229. https://doi.org/10.1037/0022-3514.59.6.1216

Gould, S., \& Hawkins, B. (1978). Organizational career stage as a moderator of the satisfaction-performance relationship. Academy of Management Journal, 21(3), 434-450. https://doi.org/10.2307/255725

Greenhaus, J. G., Callanan, G. A., \& Godshalk, V. M. (1999). Career management. New York: The Dryden Press.

Gu, Z., \& Chi, R. S. S. (2009). Drivers of job satisfaction as related to work performance in Macao casino hotels: An investigation based on employee survey. International Journal of Contemporary Hospitality Management, 21(5), 561-578. https://doi.org/10.1108/09596110910967809

Hackman, J. R., \& Oldham, G. R. (1980). Work redesign. Reading, MA: AddisonWesley.

Hackman, J. R., \& Wageman, R. (1995). Total Quality Management: empirical, conceptual, and practical issues. Administrative science quarterly, 40, 309-342. https://doi.org/10.2307/2393640

Hall, D. T., \& Nougaim, K. (1968). An examination of Maslow's hierarchy in an organizational setting. Organizational Behavior and human performance, 3(1), 12-35. https://doi.org/10.1016/0030-5073(68)90024-X

Hauff, S., Richter F. N., \& Tressin, T. (2015). Situational job characteristics and job satisfaction: The moderating role of national culture. International Business Journal, 24, 710-723. https://doi.org/10.1016/j.ibusrev.2015.01.003

Herbert, M., \& Burke, B. (1997). Determinants of job satisfaction in different career Stages. Perceptual and Motor Skills, 84 (1), 146-146. https://doi.org/10.2466/pms.1997.84.1.146

Illies, R., \& Judge, T. A. (2003). On the heritability of job satisfaction: The mediating role of personality. Journal of Applied Psychology, 88(4), 750-759. https://doi.org/10.1037/0021-9010.88.4.750

Ivancevich, M. J. (2010). Human Resouce Management, McGraw Hill/Irwin, New York.

Judge, T. A. Thoresen, C. J., Bono, J. E., \& Patton, G. K. (2001). The job satisfaction job performance relationship: A qualitative and quantitative review. Psychological Bulletin, 127, 376-407. https://doi.org/10.1037/00332909.127.3.376

Judge, T. A., \& Klinger, R. (2008). Job satisfaction: Subjective well-being at work. In M. Eid, \& R. Larsen (Eds.), The Science of Subjective Well-Being (Ch. 19, pp. 393-413). New York: Guilford Publications.

Judge, T. A., Heller, D., \& Mount, M. K. (2002). Five-Factor Model of Personality and Job satisfaction: A Meta-Analysis. Journal of Applied Psychology, Vol. 87, 530-541. https://doi.org/10.1037/0021-9010.87.3.530

Labor Force Survey. (2016). Available at: http://webrzs.stat.gov.rs/WebSite/repository/documents/00/02/45/30/ARSBi lten_623KONACNO.pdf

Larkin, I. M. (2015). Job satisfaction, organizational commitment, and turnover intention of online teachers in the K-12 setting. Doctor of Education in Instructional Technology Dissertations. Paper 2. Available from internet: http://digitalcommons.kennesaw.edu/instruceddoc_etd/2

Levinson, D. J., Darrow, C. N., Klein, E. B., Levinson, M. H., \& McKee, B. (1978). The seasons of a man's life. New York: Knopf. 
Locke, E. A. (1976). The nature and causes of job satisfaction. In M. D. Dunnette (Ed.), Handbook of Industrial and Organizational Psychology, (pp. 1297-1349). Chicago: Rand McNally College Publishing Company.

Luttman, S., Mittermaier, L., \& Rebele, J. (2003). The association of career stage and gender with tax accountants? Work attitudes and behaviors. Advances in Taxation, 15, 111-143. https://doi.org/10.1016/S1058-7497(03)15005-3

Mc Shane, S. (2004). Canadian Organizational Behaviour (5th ed.). Toronto: McGraw-Hill Ryerson.

Menguc, B., \& Bhuian, S. N. (2004). Career stage effects on job characteristic-job satisfaction relationships among guest worker salespersons. Journal of Personal Selling \& Sales Management, 24(3), 215-227.

Mount, M. K. (1984). Managerial career stage and facets of job satisfaction. Journal of Vocational Behavior, 24, $348-354$. https://doi.org/10.1016/0001-8791(84)90017-4

Obakpolo, P. Improving Interpersonal Relationship in Workplaces. Journal of Research \& Method in Education, 5(6), $115-125$.

Oshagbemi, T. (2003). Personal correlates of job satisfaction: empirical evidence from UK universities. International Journal of Social Economics, 30(12), 1210-1232. https://doi.org/10.1108/03068290310500634

Parker, S. K. (2014). Beyond Motivation: Job and Work Design for Development, Health, Ambidexterity, and More. Annual Review of Psychology, 65(1), 661-691. https://doi.org/10.1146/annurev-psych-010213-115208

RS Official Gazette 29. (2017). Available from internet: http://www.slglasnik.com/

Saeed, I., Waseem, M., Sikander, S., \& Rizwan, M. (2014). The relationship of turnover intention with job satisfaction, job performance, leader member exchange, emotional intelligence and organizational commitment. International Journal of Learning and Development, 4(2), 242-256. Available from internet: https://doi.org/10.5296/ijld.v4i2.6100.

Schmit Jongbloed L. J., Schonrock-Adema, J., Borleffs, J. C. C., Steward, R. E., \& Cohen-Schotanus, J. (2017). Physicians' job satisfaction in their begin, mid and end career stage. Journal of Hospital Administration, 6 (1), 1-8

Schneider, B., Hanges, P. J., Smith, D. B., \& Salvaggio, A. N. (2003). Which comes first: Employee attitudes or organizational financial and market performance? Journal of Applied Psychology, 88, 836-851. https://doi.org/10.1037/0021-9010.88.5.836

Slocum, J. W., \& Cron, W. L. (1985). Job attitudes and performance during three career stages. Journal of Vocational Behavior, 26(2), 126-145. https://doi.org/10.1016/0001-8791(85)90013-2

Soon Yew, J., LaiKuan, K., Zaliha H., \& Kamaruzaman, J. (2008). The influence of employee benefits towards organizational commitment. Asian social science, 4(8). 147-150.

Sousa-Pouza, A., \& Sousa-Pouza, A. A. (2000). Taking Another Look at the Gender Job/ Satisfaction Paradox. Kyklos, 53 (2), 135-152. https://doi.org/10.1111/1467-6435.00114

Spector, P. (2008). Industrial and Organisational Behaviour (5th edition). New Jersey: John Wiley \& Sons

Spector, P. E. (1997). Job Satisfaction: Application, Assessment, Causes, and Consequences. United Kingdom: Sage Publications Ltd.

Spector, P. E. (1985). Measurement of human service staff satisfaction: Development of the job satisfaction survey. American Journal of Community Psychology, 13(6), 693-713. https://doi.org/10.1007/BF00929796

Swaminathan, S. \& Jawahar, D. (2013). Job satisfaction as a predictor of organizational citizenship behavior: an empirical study. Global Journal of Business research, 7 (1), 71-80.

Thomas, A., Buboltz, W. C., \&Winkelspecht, C. S. (2004). Job Characteristics and Personality as Predictors of Job Satisfaction. Organizational Analysis, 12(2), 205-219. Available from internet: http://dx.doi.org/10.1108/eb028993

Vatsa, N. (2013). Relationship of Job Satisfaction with Organization Behavior. International Journal of Education and applied research, 3 (2), 17-21.

Wharton, A. S. Rotolo, T., \& Bird, S. R. (2000). Social context at work: a multilevel analysis of job satisfaction. Sociological Forum, 15 (1), 65-90. https://doi.org/10.1023/A:1007546120560

World Bank Group, Report No. 100464-YF. (2015). Available from internet: http://pubdocs.worldbank.org/en/11112 1446462343202/Serbia-CPF-eng-web.pdf

The article has been reviewed.

Received in July, 2017; accepted in April, 2018. 